\title{
Distribution and genetic variability of young-of-the-year greater amberjack (Seriola dumerili) in the East China Sea
}

\author{
Takamasa Hasegawa $\cdot$ Ching-Ping Lu $\cdot$ Sheng-Tai Hsiao $•$ Tsubasa Uchino $\cdot$ Hsin-Ming \\ Yeh • Wei-Chuan Chiang • June-Ru Chen • Chiyuki Sassa • Kazuyoshi Komeyama • Ryo \\ Kawabe • Takashi Sakamoto • Satoshi Masumi • Jun Uchida • Takashi Aoshima • \\ Yoshitaka Sakakura (D)
}

Received: 3 May 2019 /Revised: 4 March 2020 / Accepted: 11 May 2020 /Published online: 26 May 2020

(C) The Author(s) 2020

\begin{abstract}
We examined the distribution and genetic variability of the greater amberjack Seriola dumerili in the East China Sea (ECS) from the mitochondrial DNA (mtDNA) control region of young-of-the-year (YOY) individuals, which may reflect the genetic characteristics of the spawning population. In the years 2016 and 2017, a total of 165 YOY S. dumerili were collected from two different locations in the ECS: the southern part of the ECS, and western Japanese coast. The
\end{abstract}

Electronic supplementary material The online version of this article (https://doi.org/10.1007/s10641-020-00985-6) contains supplementary material, which is available to authorized users.

T. Hasegawa $\cdot$ Y. Sakakura $(\bowtie)$

Graduate School of Fisheries and Environmental Sciences, Organization for Marine Science and Technology, Nagasaki University, 1-14 Bunkyo-machi, Nagasaki 852-8521, Japan e-mail: sakakura@nagasaki-u.ac.jp

T. Hasegawa

Nagasaki Prefectural Institute of Fisheries, 1551-4 Taira-machi, Nagasaki 851-2213, Japan

C.-P. Lu

National Taiwan Ocean University, No.2 Peining Road, Jhongjheng District, 20224 Keelung City, Taiwan

S.-T. Hsiao · H.-M. Yeh • W.-C. Chiang · J.-R. Chen Council of Agriculture, Fisheries Research Institute, 199 Hou-Ih Road, Keelung 20246, Taiwan

T. Uchino $\cdot$ T. Sakamoto

School of Marine life Science, Tokyo University of Marine

Science and Technology, 4-5-7 Konan, Minato-ku, 108-8477 Tokyo, Japan spawning period was estimated using otolith daily increments from a total of 67 larvae and juveniles collected in the ECS. Results from size and age distribution indicated that $S$. dumerili spawned near the shelf break region in the southern ECS from January to April. Phylogenetic analysis based on mtDNA sequence data showed no significant genetic differentiation among samples collected from different locations, implying $S$. dumerili in the ECS is mainly composed of one

\section{T. Uchino}

Japan Fisheries Research and Education Agency, National Research Institute of Aquaculture, 224-1 Hiruta, Watarai-gun, Tamaki, Mei 519-0423, Japan

\section{Sassa}

Japan Fisheries Research and Education Agency, Seikai National Fisheries Research Institute, 1551-8 Taira-machi,

Nagasaki 851-2213, Japan

\section{K. Komeyama}

Graduate School of Fisheries Sciences, Hokkaido University, 3-1-1 Minato-cho, Hakodate, Hokkaido 041-8611, Japan

\section{R. Kawabe}

Institute for East China Sea Research, Organization for Marine Science and Technology, Nagasaki University, 1551-7

Taira-machi, Nagasaki 851-2213, Japan

S. Masumi · J. Uchida $\cdot$ T. Aoshima

Faculty of Fisheries, Nagasaki University, 1-14 Bunkyo-machi, Nagasaki 852-8521, Japan 
population. S. dumerili around the Japanese coast may be originated from the southern ECS.

Keywords Mitochondrial DNA · Otolith · Genetic variation $\cdot$ Population structure $\cdot$ Early life history

\section{Introduction}

The greater amberjack Seriola dumerili (family Carangidae) is a marine pelagic species with circumglobal distribution from temperate to tropical waters (Taki et al. 2005). This species is valuable for commercial and recreational fisheries (Gold and Richardson 1998) and aquaculture (Nakada 2002, 2008). Juveniles of $S$. dumerili of $1.7-29.7 \mathrm{~cm}$ in standard length (SL) associate with floating objects such as drifting seaweeds (Badalamenti et al. 1995; Yamasaki et al. 2014; Hasegawa et al. 2017a). The young fish then leave the drifting seaweeds and shift their habitat to the middle or bottom layer as they grow (Uchida et al. 1958), frequently concentrating around reefs, rock outcrops and wrecks (Manooch and Potts 1997). Off the Atlantic coast in the southeastern U.S., females become mature at $1-5$ years of age (51.4-82.6 cm in fork length) with 1.3 years being the mean age at which $50 \%$ of females are mature (25-47 million oocytes per female), indicating that they grow quickly, mature early, and exhibit high fecundity (Harris et al. 2007). Since this species distributes all over the world, several different populations are recognized, two in the U.S. coast and two in the eastern Asia. A tagging survey (over 1400 recaptures from approximately 14,000 releases) revealed the existence of two stocks or subpopulations of $S$. dumerili in the western Atlantic from the U.S. coast to the Gulf of Mexico (Cummings and Mcclellan 1996). The results of Gold and Richardson (1998) supported the existence of these two subpopulations of $S$. dumerili in U.S. waters based on variations in the restriction sites of mitochondrial (mt) DNA.

Nugroho et al. (2000) examined genetic variations of $S$. dumerili for aquaculture seedlings in Japan which were captured from Vietnam and coastal waters of Japan, respectively, using polymorphism of the mtDNA D-loop and microsatellite DNA markers. They revealed that at least two genetically different subpopulations existed, which originated from Vietnam and Japan, respectively. Araki et al. (2018) also discriminated two subpopulations of $S$. dumerili captured off the Hainan
Islands, China (in the South China Sea: SCS) and Kochi, Japan (Pacific coast) by structural variations of resequenced genome data. From these evidences, there may be two subpopulations of $S$. dumerili in Asia: the population in the East China Sea (ECS) and that in the SCS.

Hasegawa et al. (2017b) collected larval and earlyjuvenile $S$. dumerili (11-51 days after hatching) near the Penghu islands, Taiwan (Fig. 1) and posited that the open water area off the Penghu islands is one of the spawning grounds of $S$. dumerili. Larvae and earlyjuvenile of $S$. dumerili are not common around the Japanese coastal area (Uchida et al. 1958), while the relatively large size of the juveniles associated with drifting seaweed occurs on the western Japanese coast of the ECS from July (Fujita and Mori 1982). The Kuroshio Current and the Tsushima Warm Current (TSWC) affect the transportation of fish eggs, larvae and juveniles (e.g., see Fukataki 1960; Sassa et al. 2008; Sassa and Tsukamoto 2010; Fig. 1). As for the congeneric yellowtail ( $S$. quinqueradiata), the major spawning has been shown to occur from January to June at around the edge of the continental shelf in the ECS, and juveniles of $S$. quinqueradiata hatched in the ECS are transported to the coastal area of Japan with drifting seaweeds by the Kuroshio Current and/or TSWC (Yamamoto et al. 2007). Similar to S. quinqueradiata, S. dumerili hatched in the southern part of the ECS near Taiwan are transported to the Japanese coast with drifting seaweeds. Therefore, we hypothesized that young-of-the-year (YOY) S. dumerili in the ECS from Taiwan to the Japanese coast are composed of one population.

Highly migratory marine teleosts occur throughout large portions of the world's oceans due to their cosmopolitan distributions, and thus analysis of the population structure of these circumglobal fishes is complicated by their ubiquity (Carlsson et al. 2004). In the ECS, information on the migration of adult $S$. dumerili is lacking, and because these fish have the potential to migrate over extensive distances, determination of their genetic population structure would be very difficult. It is likely that YOY fish better reflect the genetic composition of the spawning population compared to older fish with greater migratory capacity (Graves et al. 1996; Carlsson et al. 2004). Thus, we speculated that we could identify the spawning population of $S$. dumerili in the ECS by targeting YOY fish. 


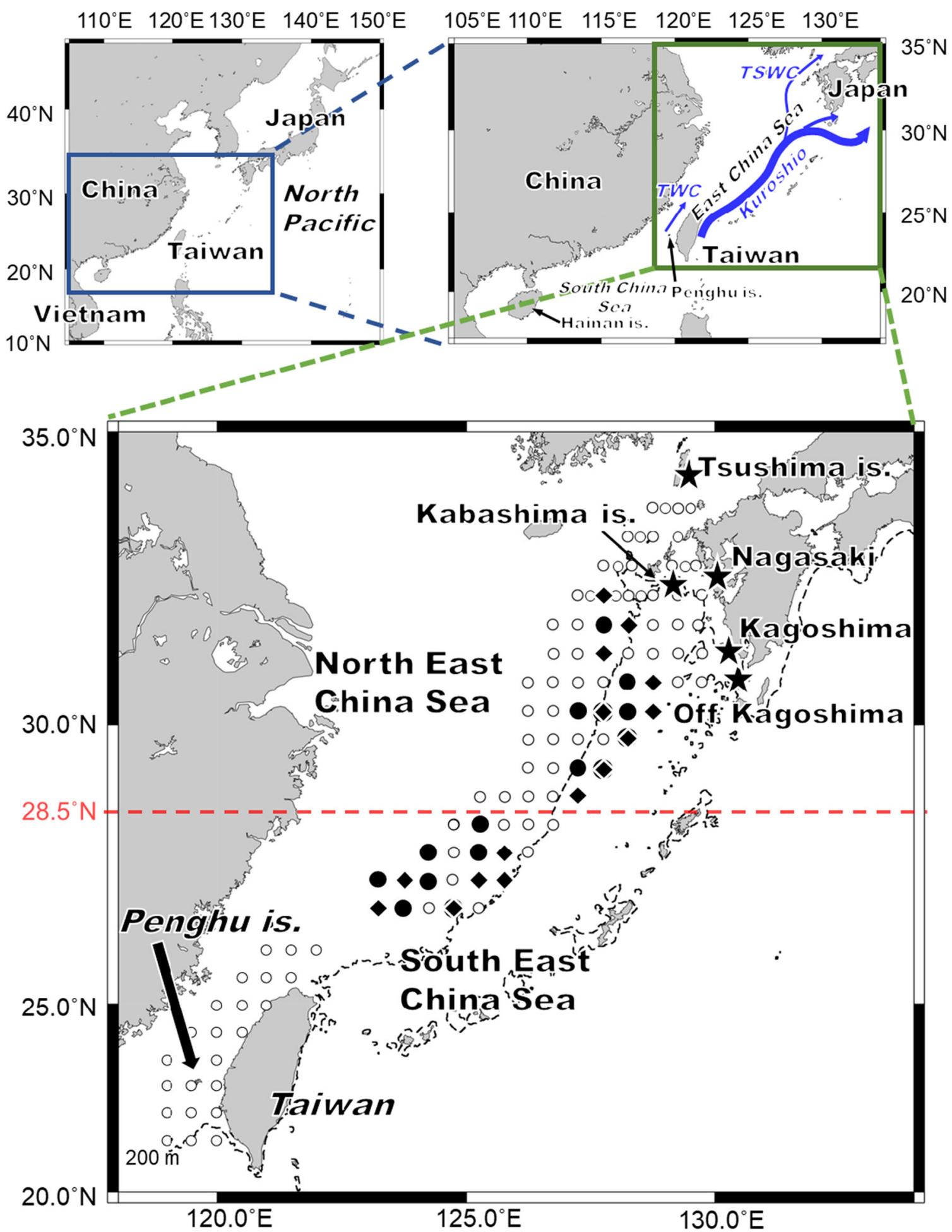

Fig. 1 Geographical location of sampling sites in the East China Sea in the years 2016 and 2017. Circles are the sampling stations by research vessels in this study; $S$. dumerili were collected at the stations with filled circles in 2016 and with filled diamonds in
2017. Stars represent stations where $S$. dumerili were collected by angling, or with a fixed net (see Table 1 for details). The $200 \mathrm{~m}$ isobath is shown with dashed thin lines. TWC and TSWC are the Taiwan Warm Current and Tsushima Warm Current, respectively 
In the present study, we first examined the distribution and ages (days after hatching) of YOY S. dumerili using daily increments in otoliths. We also estimated the spawning period and spawning ground from their ages and the ocean currents, because we considered that information on the spawning period and spawning ground could facilitate our understanding of the genetic variability of $S$. dumerili. Secondly, we examined the genetic variability of YOY S. dumerili from the ECS by mtDNA sequencing. Finally, we discussed the early life history of $S$. dumerili in the ECS based on aging and genetic variability, and the importance of fishery management for this species in the ECS.

\section{Materials and methods}

Sample collection

We conducted sampling at three geographic locations in the ECS: around Taiwan, around the edge of the continental shelf in the ECS and along the western Japanese coast (Fig. 1). Larvae and juveniles (under $10 \mathrm{~cm}$ in total length: TL) were collected in the shelf-break region of the ECS during the cruise of the RV "Yoko-Maru" (Seikai National Fisheries Research Institute, Fisheries Research and Education Agency) between 11 and 28 April 2016 and between 11 and 29 April 2017, respectively (Fig. 1). A neuston net (mouth size $1.3 \times 0.75 \mathrm{~m}$, mesh size $1.0 \mathrm{~mm}$; Oozeki et al. 2001) was towed for
10 min with a towing speed of 3.5 knots at the upper $0.75 \mathrm{~m}$ layer in 77 stations in 2016 and 90 stations in 2017. Specimens were fixed in $10 \%$ buffered formalin seawater for $6 \mathrm{~h}$, formalin was rinsed out with freshwater, and then the specimens were transferred into $90 \%$ ethanol solution for preservation. Along the southwestern to northwestern part of Taiwan, larvae and juveniles were collected during the cruise of the $\mathrm{R} / \mathrm{V}$ "Fishery Researcher 1" (Taiwan Fishery Research Institute, Council of Agriculture) between 22 and 25 April 2017 (Fig. 1). Surface tows of an ORI net (mouth size $\Phi 1.6 \mathrm{~m}$, mesh size $0.33 \mathrm{~mm}$ ) during daytime $(0600-1830 \mathrm{~h} \mathrm{Na}-$ tional Standard Time) in 17 stations and oblique tows of an ORI net from the surface down to $50 \mathrm{~m}$ depth during night time (19:00-05:30 h National Standard Time) in seven stations were conducted. The ORI net was towed for $10 \mathrm{~min}$ with a towing speed of 2 knots. Specimens were preserved in $95 \%$ ethanol solution for $6 \mathrm{~h}$, and then transferred into fresh $95 \%$ ethanol solution. From collected larvae and juveniles, S. dumerili was identified according to Okiyama $(1988,2014)$.

Along the western Japanese coast in the ECS, young fish (over $10 \mathrm{~cm}$ in TL) were collected by angling from the T/V "Kakuyo-Maru" (Nagasaki University), and from private set nets in Nagasaki and Kagoshima Prefecture, Japan (Fig. 1) between 6 July and 6 September 2016 and between 26 August and 28 September 2017, respectively (Table 1). Specimens were kept frozen until measurement. All the individuals were grouped by geographic regions: Tsushima island $(\mathrm{n}=28)$, Kabashima

Table 1 Collection date, area and body size of young-of-year (YOY) S. dumerili collected in the present study. ECS means the East China Sea

\begin{tabular}{|c|c|c|c|c|c|c|c|c|c|}
\hline \multirow[t]{2}{*}{ Year } & \multicolumn{5}{|l|}{ Collection } & \multicolumn{4}{|c|}{ Total length (cm) } \\
\hline & Area $^{*}$ & Date & Long. $\left({ }^{\circ} \mathrm{E}\right)$ & Lat. $\left({ }^{\circ} \mathrm{N}\right)$ & Method & $\mathrm{n}$ & Mean \pm S.D. & Min. & Max. \\
\hline \multirow[t]{4}{*}{2016} & North part of the ECS & 13-18 Apr & $127^{\circ} 45-128^{\circ} 15$ & $29^{\circ} 25-30^{\circ} 25$ & Neuston net & 13 & $1.7 \pm 1.0$ & 0.7 & 3.9 \\
\hline & South part of the ECS & 23-25 Apr & $123^{\circ} 15-125^{\circ} 15$ & $26^{\circ} 75-28^{\circ} 25$ & Neuston net & 11 & $1.6 \pm 1.0$ & 0.6 & 4.1 \\
\hline & Kagoshima, Japan & 24 Aug & $130^{\circ} 08$ & $31^{\circ} 25$ & Fixed net & 34 & $26.7 \pm 2.2$ & 20.0 & 29.5 \\
\hline & Nagasaki coast, Japan & 6 Jul-6 Sep & $129^{\circ} 45-129^{\circ} 49$ & $32^{\circ} 43$ & Angling & 5 & $26.1 \pm 5.3$ & 16.9 & 29.8 \\
\hline \multirow[t]{6}{*}{2017} & North part of the ECS & 13-27 Apr & $127^{\circ} 15-128^{\circ} 45$ & $28^{\circ} 75-32^{\circ} 24$ & Neuston net & 26 & $2.8 \pm 1.9$ & 0.5 & 7.2 \\
\hline & South part of the ECS & 19-24 Apr & $123^{\circ} 15-125^{\circ} 45$ & $26^{\circ} 75-27^{\circ} 75$ & Neuston net & 17 & $2.1 \pm 1.1$ & 0.4 & 4.6 \\
\hline & Off Kagoshima, Japan & $26 \mathrm{Jul}$ & $130^{\circ} 10$ & $31^{\circ} 11$ & Angling & 7 & $18.7 \pm 2.2$ & 15.1 & 21.2 \\
\hline & Nagasaki coast, Japan & 27 Jul-28 Sep & $129^{\circ} 26-130^{\circ} 05$ & $32^{\circ} 34-33^{\circ} 00$ & Angling & 8 & $23.1 \pm 6.1$ & 11.6 & 29.6 \\
\hline & Kabashima Is., Japan & $20 \mathrm{Jul}-26 \mathrm{Sep}$ & $128^{\circ} 59-129^{\circ} 00$ & $32^{\circ} 44-32^{\circ} 46$ & Angling & 15 & $22.6 \pm 4.9$ & 11.7 & 29.6 \\
\hline & Tsushima Is., Japan & 11-16 Aug & $129^{\circ} 17-129^{\circ} 19$ & $34^{\circ} 32-34^{\circ} 33$ & Fixed net & 29 & $26.6 \pm 1.7$ & 22.5 & 29.3 \\
\hline
\end{tabular}

* Area is shown in Fig. 1 in detail 
island ( $\mathrm{n}=15)$, Nagasaki coast $(\mathrm{n}=13)$, Off Kagoshima $(n=41)$, Northern part of the ECS $(n=34)$, or Southern part of the ECS $(n=25)$. Then, the collecting year was prefixed to the geographic region to create four groups for further molecular analyses: 16ECS $(n=24)$, 16Japan $(\mathrm{n}=39)$, 17ECS $(\mathrm{n}=43)$ and 17Japan $(\mathrm{n}=59)$ (Table 1).

The total lengths (TL cm) of $S$. dumerili were measured using a digital microscope (Keyence, VH6300) or digital caliper. Since many of the specimens collected from the ECS in 2016 were damaged due to sampling, making it difficult to measure the total length, TL was estimated from SL using the following equation: $\left(\mathrm{R}^{2}\right.$ $=0.99$ ). This equation was calculated from $S$. dumerili collected in the ECS $(0.4-7.2 \mathrm{~cm}$ in TL, $\mathrm{n}=43)$ and along the western Japanese coast (11.6-40.3 cm in TL, $\mathrm{n}=79$ ) in 2017 (Fig. 1). After measurement, a piece of a fin or the whole body (in the case of fish under $10 \mathrm{~cm}$ in TL) was individually preserved in $95 \%$ ethanol solution or RNA later (Qiagen, Valencia, ca.) for DNA extraction.

Age determination of YOY S. dumerili from the ECS

Larval and juvenile $S$. dumerili deposit otolith increments on a daily basis (Hasegawa et al. 2017b). Pairs of sagittal otoliths were extracted under a dissecting microscope. The otoliths were laid on a glass slide and embedded in epoxy resin. Then, the otoliths were observed after grinding using lapping film $(9 \mu \mathrm{m}$ and 3 $\mu \mathrm{m})$. Otolith increments were counted under a light microscope at a magnification of 1000 using an oil immersion lens. Since the daily increments in the otoliths of large fish (over $10 \mathrm{~cm}$ in TL) were not clear in our study, we defined YOY S. dumerili as individuals under $30 \mathrm{~cm}$ in TL $(24.7 \mathrm{~cm}$ in SL, calculated from the above equation), according to the growth rate on the U.S. Atlantic coast, where YOY S. dumerili grow approximately $25 \mathrm{~cm}$ in SL $(30.4 \mathrm{~cm}$ in TL, calculated using the above equation) in 6 months (Wells and Rooker 2004) and where one-year-old fish exceed $40 \mathrm{~cm}$ in fork length (Harris et al. 2007).

To compare the distribution and spawning period of S. dumerili between geographic regions, we divided our study area into the following two subareas: the northern part of the ECS between $33.0^{\circ} \mathrm{N}$ and $28.5^{\circ} \mathrm{N}$, and the southern part of the ECS between $28.5^{\circ} \mathrm{N}$ and $26.5^{\circ} \mathrm{N}$ (Fig. 1), since latitudinally discriminated distributions of S. dumerili in the ECS were observed both in 2016 and 2017 (Fig. 1).
Sequencing of the mitochondrial DNA control region

DNA was extracted by a standard phenol-chloroform method or by using the DNeasy Blood \& Tissue Kit (Qiagen) following the manufacturer's instructions. The $S$. dumerili mtDNA genome sequence was obtained from the European Nucleotide Archive database (accession No. AB517558.1) and the specific primers for amplifying the control region (CR) of the mtDNA of S. dumerili (GA-F: 5'- TGC TCA GAG AAA GGG GAC TT-3'; GA-R: 5'-GGA CCA AAC CTT TGT GCT TG-3') were designed using the Primer 3 program (Untergasser et al. 2012). PCR amplifications were performed in a $9 \mu 1$ reaction volume containing 10x Ex Taq Buffer (Takara Bio, Shiga, Japan), 2.5 mM dNTP mixture (Takara Bio), $0.025 \mu \mathrm{M}$ each of forward and reverse primers, and $0.05 \mu \mathrm{l}$ of $5 \mathrm{U} / \mu \mathrm{l}$ Ex Taq (Takara Bio), and $1.0 \mu \mathrm{l}$ of template DNA containing approximately $30-100 \mathrm{ng} / \mathrm{ml}$ of DNA. The PCR amplifications were programmed as an initial denaturation at $95^{\circ} \mathrm{C}$ for $3 \mathrm{~min}$; one cycle of $94^{\circ} \mathrm{C}$ for $30 \mathrm{~s}, 62^{\circ} \mathrm{C}$ for $30 \mathrm{~s}$ and 72 ${ }^{\circ} \mathrm{C}$ for $1 \mathrm{~min}$; one cycle of $94{ }^{\circ} \mathrm{C}$ for $30 \mathrm{~s}, 60{ }^{\circ} \mathrm{C}$ for $30 \mathrm{~s}$ and $72{ }^{\circ} \mathrm{C}$ for $1 \mathrm{~min}$; one cycle of $94{ }^{\circ} \mathrm{C}$ for $30 \mathrm{~s}, 58^{\circ} \mathrm{C}$ for $30 \mathrm{~s}$ and $72{ }^{\circ} \mathrm{C}$ for $1 \mathrm{~min}$; one cycle of $94{ }^{\circ} \mathrm{C}$ for $30 \mathrm{~s}$, $56^{\circ} \mathrm{C}$ for $30 \mathrm{~s}$ and $72{ }^{\circ} \mathrm{C}$ for $1 \mathrm{~min} ; 28$ cycles of $94^{\circ} \mathrm{C}$ for $30 \mathrm{~s}, 55^{\circ} \mathrm{C}$ for $30 \mathrm{~s}$ and $72^{\circ} \mathrm{C}$ for $1 \mathrm{~min}$; followed by a final extension at $72{ }^{\circ} \mathrm{C}$ for $5 \mathrm{~min}$. Each PCR product was evaluated in $2 \%$ agarose gel electrophoresis with a standard size marker (TaKaRa Bio). PCR products were purified with illustra ExoProStar (GE Healthcare, Milwaukee, WI) and ExoSAP-IT Express PCR Product Cleanup (Affymetrix, Santa Clara, ca.). The mtDNA $\mathrm{CR}$ was sequenced in both directions with the PCR forward and reverse primers. The reactions of DNA sequencing were performed by the FASMAC Co. (Kanagawa, Japan), and Eurofin Genomics (Tokyo), except in the case of $16 \mathrm{~s}$. For $16 \mathrm{~s}$, sequencing PCR with forward and reverse primers was performed using a BigDye Terminator v3.1 Cycle Sequencing Kit (Applied Biosystems). After purification with BigDye XTerminator (Applied Biosystems), the DNA sequencing reaction products were run on an Applied Biosystems 3130xl DNA Analyzer (ThermoFisher Scientific).

Molecular diversity index and genetic differentiation

The alignments of multiple sequences were performed with CLUSTALW (Thompson et al. 1994) in MEGA X 
(Kumar et al. 2018) using default settings. The number of mitochondrial haplotypes, polymorphic sites, haplotype diversity $(H d)$, and nucleotide diversity $(\pi)$ were estimated in DnaSP v6 (Rozas et al. 2017). Nucleotide sequence data for the haplotypes used in this paper were deposited in GenBank under accession numbers MT027362-MT027489. The mtDNA CR sequences were analyzed to estimate the index of genetic differentiation $\left(\mathrm{F}_{\mathrm{ST}}\right)$ and gene flow $(\mathrm{Nm})$ between sampling localities pairs, and by the analysis of molecular variance (AMOVA) (Excoffier et al. 1992) under alternative hierarchical arrangements to analyze the population differentiation in Arlequin v3.5 (Excoffier and Lischer 2010). The minimum spanning network cladogram was estimated by TCS v 1.21 (Posada and Crandall 2001) using the parsimony method.

\section{Results}

Fish collection

From various geographic locations in the ECS, 63 specimens were collected in 2016 and 106 specimens were collected in 2017. Around the edge of the continental shelf in the ECS, a total of 24 and 43 specimens were collected from 15 stations in 2016 and 2017, respectively (Fig. 1; Table 1). The TLs of $S$. dumerili from the ECS ranged between 0.6 and $4.1 \mathrm{~cm}$ in 2016 and between 0.4 and $7.2 \mathrm{~cm}$ in 2017 (Fig. 2; Table 1). There were significant difference in TLs between 2016 and 2017 of the ECS, but not between northern and southern part of the ECS (Two-way ANOVA, year: $\mathrm{df}=1, \mathrm{~F}=$ 5.531, $\mathrm{p}<0.05$, location: $\mathrm{df}=1, \mathrm{~F}=2.150, \mathrm{p}=0.148$, year $\times$ location: $\mathrm{df}=1, \mathrm{~F}=0.928, \mathrm{p}=0.339$ ). Along the western Japanese coast in the ECS, a total of 39 (16.9$29.8 \mathrm{~cm}$ in TL) and 59 (11.6-29.6 cm in TL) S. dumerili were collected in 2016 and 2017, respectively (Table 1). From the southwestern to northern part of Taiwan, S. dumerili was not collected by surface towing of an ORI net in 2017.

\section{Age determination}

We determined the age of all the specimens both in the year 2016 and the year 2017 from the ECS. The age (days after hatching) of specimens from the ECS ranged between 9 and 62 in 2016 and between 9 and 82 in 2017 , respectively (Figs. 2 and 3). We then estimated their spawning periods from February to April in 2016 and January to April in 2017 (Fig. 2). Larvae collected in 2017 hatched at earlier month than those in 2016, and fish from northern part of the ECS hatched earlier than those of southern part of the ECS (Two-way ANOVA, year: $\mathrm{df}=1, \mathrm{~F}=5.060, \mathrm{p}<0.05$, location: $\mathrm{df}=1, \mathrm{~F}=$ $8.520, \mathrm{p}<0.01$, year $\times$ location: $\mathrm{df}=1, \mathrm{~F}=0.376, \mathrm{p}=$ $0.542)$. The growth curves between age ( $x_{\text {day }}$, days after hatching) and TL $\left(y_{\mathrm{TL}}, \mathrm{cm}\right)$ were described by the following equations: $(\mathrm{n}=24, r=0.96)$ for 2016 and $(\mathrm{n}=$ $43, r=0.96$ ) for 2017 (Fig. 3). Individuals with different body size and age were dispersedly distributed in the southern and northern part of the ECS, and there was no discernible trend in the distribution of large size and early hatched fish in the northern part of the ECS (Fig. 2).

Molecular diversity indices

A total 683 bp of mtDNA CR sequences (Supplementary Table 1) were used to characterize the genetic diversity of the western Japanese coast and ECS $S$. dumerili populations. There was no significant difference among sampling years (2016, 2017) or hierarchical geographical locations in the analysis of molecular variance (AMOVA) test (Table 2). Both Slatkin's linearized $\mathrm{F}_{\mathrm{ST}}$ and pairwise $\mathrm{F}_{\mathrm{ST}}$ calculated from mtDNA $\mathrm{CR}$ data revealed values near zero and negative values (data not shown, $p>0.05$, ns). The results showed that there was no difference among the four groups in the ECS. With the AMOVA results, in the one-group AMOVA test, the majority of the variation in $S$. dumerili was observed among individuals within populations $\left(\Phi_{\mathrm{ST}}=-0.00737, \mathrm{p}>0.001, \mathrm{~ns}\right)$. With multiple alternative grouping, there was no significant difference between the ECS and western Japanese coast $\left(\Phi_{\mathrm{CT}}=0.00098, \mathrm{p}>0.001\right.$, ns), and no significant difference between 2016 and 2017 ( $\Phi_{\mathrm{CT}}$ $=-0.00066, \mathrm{p}>0.001$, ns). Thus we combined the year 2016 and 2017 samples and retained the hierarchical geographical locations for molecular analyses. Genetic variation among the Western Japanese coast and ECS populations revealed very high numbers of haplotypes and high levels of haplotype diversity (Table 2). A total of 128 haplotypes were identified within 156 specimens with an average haplotype diversity of $0.997 \pm 0.001$. Haplotype diversity ranged from 0.993 to 1 among populations. The populations of Tsushima Island, Kabashima 

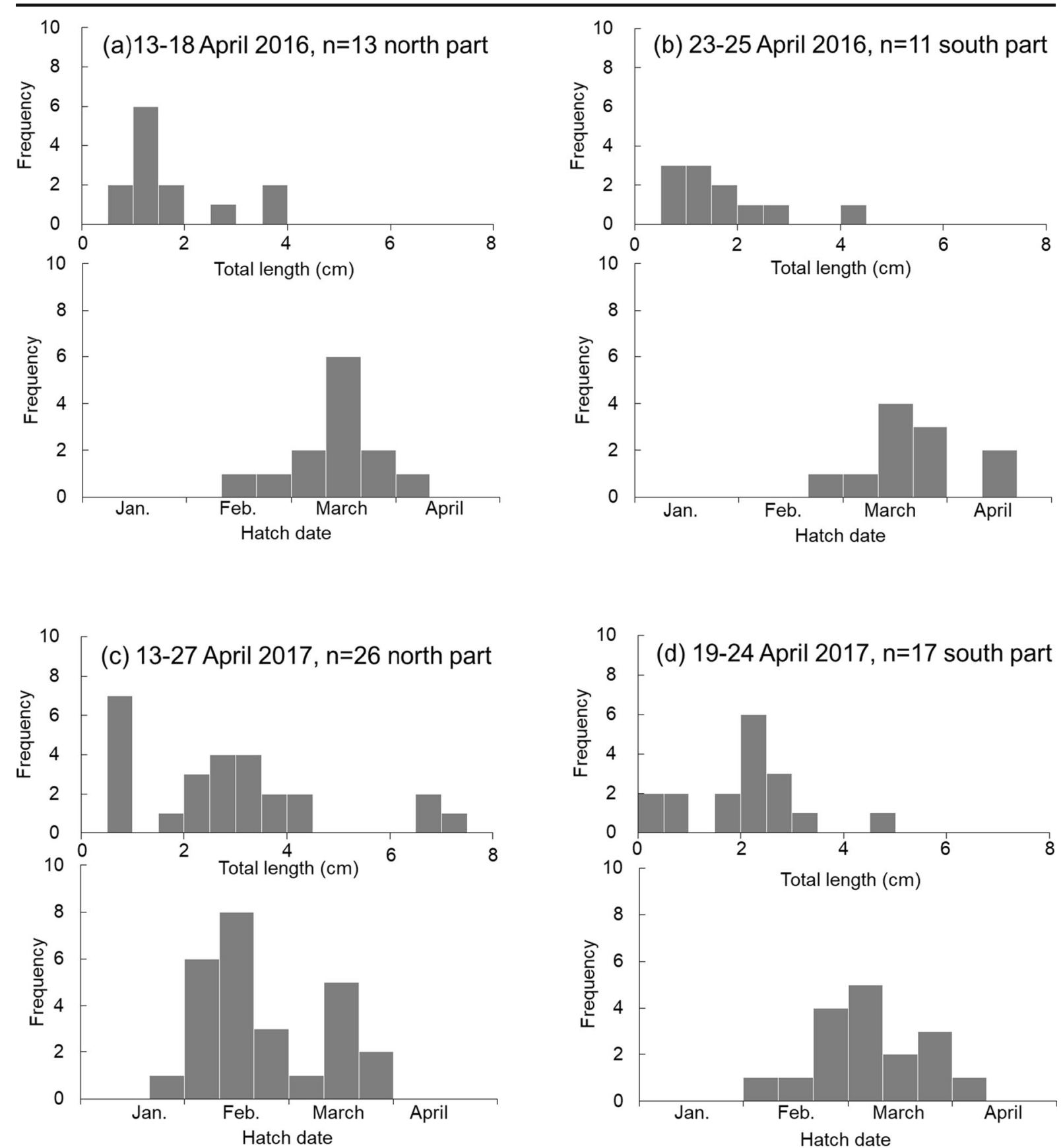

Fig. 2 Size and hatch dates distribution of $S$. dumerili collected in the northern and southern parts of the East China Sea in 2016 and 2017. Collection dates, locations and sample size are indicated in each histogram

Island, the Nagasaki coast and the North East China Sea had the highest haplotype diversity value $(H d=$ 1), while the South East China Sea displayed the lowest haplotype diversity $(H d=0.993 \pm 0.013)$, although even that was a relatively high value
(Table 3). These results showed that the mtDNA $\mathrm{CR}$ of the $S$. dumerili exhibited high diversity and was less conserved. The average number of nucleotide differences $(\mathrm{k})$ and average value of nucleotide diversity were 12.068 and $0.0177 \pm 0.00069$, ranging 
Fig. 3 Growth of young-of-year (YOY) $S$. dumerili collected in the East China Sea in 2016 and 2017

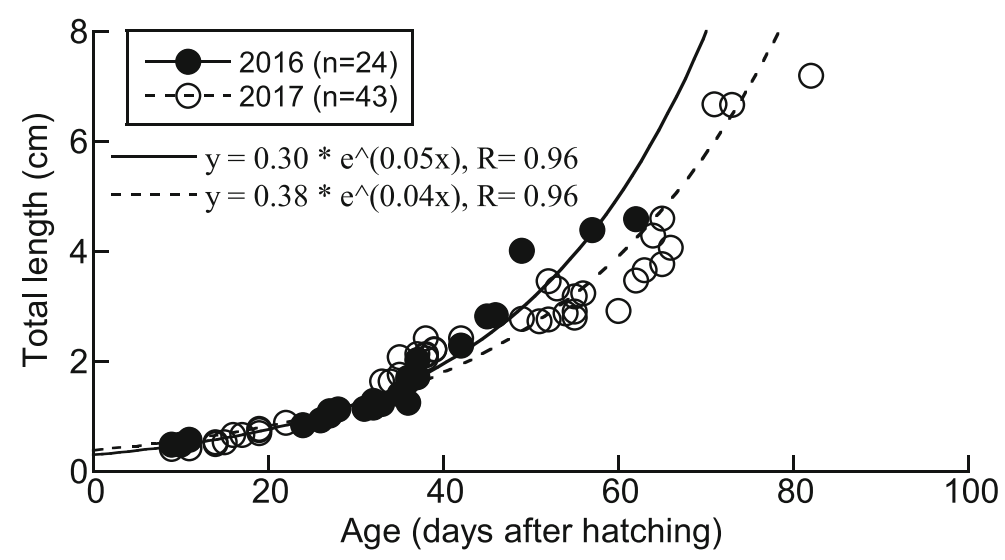

from 10.936 to 13.68 and $0.01602 \pm 0.00105$ to $0.02006 \pm 0.00126$, respectively. The southern ECS displayed the highest value of nucleotide diversity $(\pi=0.01917)$ and the Off Kagoshima region had the lowest nucleotide diversity value $(0.01602 \pm$ 0.00105). Neutrality indices calculated by Fu's Fs test were negative in all populations and showed significant differences $(\mathrm{p}<0.01)$. These results, like those for haplotype diversity, showed an excess number of alleles, as would be expected from the recent population expansions of YOY Seriola dumerili in the Western Japanese coast and ECS, or the genetic hitchhiking effect impacting the YOY $S$. dumerili mtDNA CR region. The minimum spanning network cladogram shows that the alleles were rarely shared among populations (Fig. 4). Most haplotypes were detected only once and showed a large number of connections between populations.

Pairwise genetic difference analysis

For the pairwise comparisons of population genetic differentiation (Fst), we found there was low genetic differentiation between the ECS and western Japanese coast (Table 4). There was no differentiation between the ECS and most of the western Japanese coast except off Kagoshima. Also, the same results were found that there was no differentiation among Tsushima Island and others except off Kagoshima. Thus, the gene flow between the

Table 2 Analyses of molecular variance (AMOVA) to detect population differentiation by year and localities grouping test

\begin{tabular}{lllll}
\hline Source & d.f. & Sum of squares & Variance components & Significance tests (P-value) \\
\hline Among groups (year 2017 vs. 2016) & 1 & 4.137 & -0.04 & $0.425 \pm 0.016$ \\
Among populations within group & 2 & 20.5 & 0.294 & $0.275 \pm 0.015$ \\
Within populations & 152 & 912.587 & 6.044 & $0.425 \pm 0.017$ \\
Total & 155 & 937.224 & 6.033 & $0.49 \pm 0.015$ \\
Among groups (Japan coast vs. ECS ) & 1 & 4.633 & -0.029 & $0.339 \pm 0.014$ \\
Among populations within group & 2 & 20.004 & 0.022 & $0.387 \pm 0.012$ \\
Within populations & 152 & 912.587 & 6.044 & $0.697 \pm 0.013$ \\
Total & 155 & 937.224 & 6.037 & $0.446 \pm 0.015$ \\
Among groups (island vs. coast vs. ECS) & 2 & 0.95 & -0.0005 & $0.706 \pm 0.016$ \\
Among populations within group & 3 & 1.5 & 0.00007 & 0.498 \\
Within populations & 150 & 74.836 & 0.498 & \\
Total & 155 & 77.288 &
\end{tabular}

There were no significant differences by any of the three different groupings. Statistical significance test: $\mathrm{P}<0.05$ 
Table 3 Diversity and neutrality indices of young-of-year (YOY) Seriola dumerili in the populations of the Western Japanese coast and East China Sea revealed by mitochondrial DNA control region (D-Loop) sequences

\begin{tabular}{llllllll}
\hline Site & $\mathrm{n}$ & $\mathrm{h}$ & $\mathrm{S}$ & $\mathrm{k}$ & Haplotype diversity \pm S.D & Nucleotide diversity \pm S.D & Fu's Fs test \\
\hline Tsushima Island & 28 & 28 & 66 & 13.114 & $1 \pm 0.010$ & $0.01920 \pm 0.00118$ & $-18.404 * *$ \\
Kabashima Island & 15 & 15 & 50 & 11.410 & $1 \pm 0.024$ & $0.01671 \pm 0.00172$ & $-6.740^{* *}$ \\
Nagasaki coast & 13 & 13 & 40 & 12.321 & $1 \pm 0.030$ & $0.01804 \pm 0.00236$ & $-4.868^{* *}$ \\
Off Kagoshima & 41 & 36 & 60 & 10.936 & $0.994 \pm 0.007$ & $0.01602 \pm 0.00105$ & $-22.590^{* *}$ \\
Western Japanese coast & 97 & 84 & 87 & 11.758 & $0.997 \pm 0.002$ & $0.01721 \pm 0.00069$ & $-89.749 * *$ \\
North East China Sea & 34 & 34 & 66 & 11.708 & $1 \pm 0.007$ & $0.02006 \pm 0.00126$ & $-27.569 * *$ \\
South East China Sea & 25 & 23 & 60 & 13.680 & $0.993 \pm 0.013$ & $0.01855 \pm 0.00091$ & $-9.157 * *$ \\
East China Sea & 59 & 56 & 80 & 12.629 & $0.998 \pm 0.004$ & $0.0177 \pm 0.00055$ & $-163.573^{* *}$ \\
Total & 156 & 128 & 98 & 12.068 & $0.997 \pm 0.001$ &
\end{tabular}

A total 683 bp of mtDNA CR sequences were used in the molecular analysis. n: number of sequences; h: number of haplotypes, S: number of polymorphic sites; k: average number of nucleotide differences. Fu's Fs test for statistical significance: $* * \mathrm{P}<0.01$

ECS and western Japanese coast was highly connective. According to the results of the analyses using mtDNA CR sequences, there was no significant population differentiation and high connectivity among $S$. dumerili samples between the ECS and western Japanese coast.

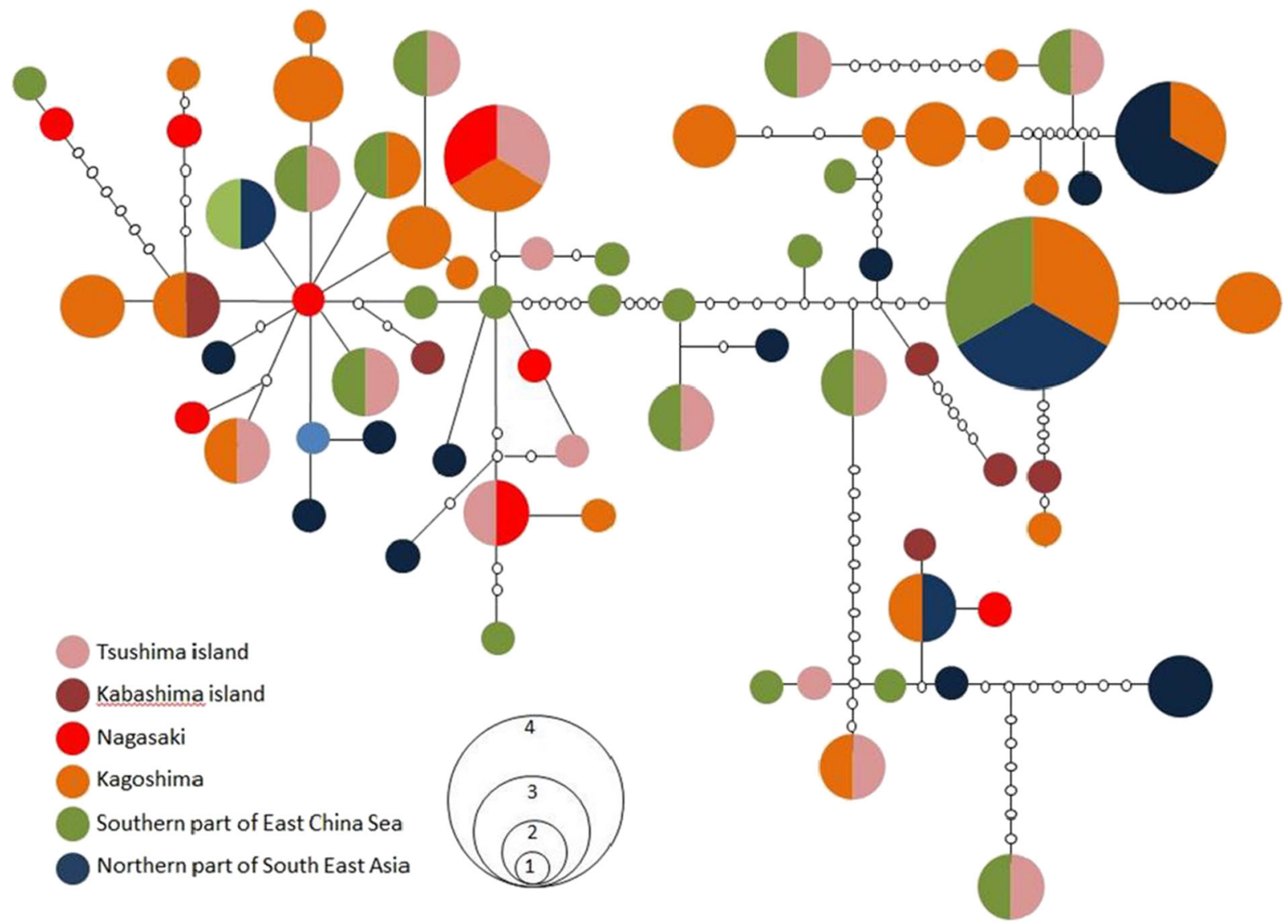

Fig. 4 The minimum spanning network cladogram revealed by mtDNA CR haplotype 
Table 4 Pairwise genetic difference (Fst in lower diagonal) and gene flow (Nm in upper diagonal) of Seriola dumerili of Western Japanese coast and East China Sea populations from mitochondrial DNA control region

\begin{tabular}{|c|c|c|c|c|c|c|}
\hline Fst $\backslash \mathrm{Nm}$ & Tsushima island & Kabashima island & Nagasaki coast & Off Kagoshima & NECS & SECS \\
\hline Tsushima island & & $\infty$ & $\infty$ & 513.2 & $\infty$ & $\infty$ \\
\hline Kabashima island & 0 & & $\infty$ & 320.3 & 268.5 & $\infty$ \\
\hline Nagasaki coast & -0.00831 & 0 & & 372.5 & 265.7 & $\infty$ \\
\hline Off Kagoshima & -0.00040 & 0.00156 & 0.00134 & & $\infty$ & 513.2 \\
\hline NECS & -0.00616 & -0.00191 & -0.00220 & 0.00097 & & $\infty$ \\
\hline SECS & 0.00180 & 0.00186 & 0.00188 & -0.00020 & -0.00059 & \\
\hline
\end{tabular}

NECS represented North East China Sea, SECS represented South East China Sea, Nm represented numbers of migrants, $\infty$ represented highly connectivity. There were no significance differences of $\mathrm{p}$ value $(\alpha=0.05)$ among populations differentiation

\section{Discussion}

Spawning period and ground

In the present study, the spawning period of $S$. dumerili from the ECS was from January to April. Previous studies in other waters also reported that the majority of spawning of $S$. dumerili occurs between winter and summer: from February to April by hatching date analysis off Galveston, Texas in the U.S. (Wells and Rooker 2004), from January to June with peak spawning in April and May in the South Atlantic (Sedberry et al. 2006) and off the Atlantic coast in the Southeastern U.S. (Harris et al. 2007), in winter in the western Atlantic (Fahay 1975) and in June and July in the Mediterranean Sea (Raya and Sabatés 2015). Hasegawa et al. (2017b) showed that spawning of $S$. dumerili around Taiwan occurs from April to June.

In our study, early larvae ( $<9$ days after hatching) were collected, and their distribution and hatch dates postulated that $S$. dumerili larvae hatched around the edge of the continental shelf in the southern ECS and were transported northward in the ECS. Thus, we postulate that one of the spawning grounds of $S$. dumerili is around the edge of the continental shelf in the southern ECS. In the southern U.S., the spawning ground of S. dumerili is estimated to be around the shelf-edge reef sites of 50-100 m depth (Sedberry et al. 2006). Sassa et al. (2016) suggested that the spawning ground of Japanese jack mackerel Trachurus japonicus was formed in a rather confined area in the southern ECS, because the centers of distribution of the larval T. japonicus in the southern ECS did not differ among the 12 years surveyed. However, S. dumerili individuals with different body size and age were dispersedly distributed in the southern and northern parts of the ECS, indicating that the spawning ground of $S$. dumerili is widely formed along the edge of the continental shelf of 50-100 m depth in the southern ECS. In addition, S. dumerili was not collected from the southwestern to northwestern part of Taiwan in 2017. There are three possible reasons for this result. One is that the majority of spawning grounds of S. dumerili are distributed in the shelf break region of northern Taiwan in the southern ECS. The second is that the dearth of $S$. dumerili was due to a gear bias or an inadequate net-towing speed, which could have disturbed the capture of larvae and juvenile $S$. dumerili. Third, the spawning of $S$. dumerili had finished around Taiwan in April 2017, and the larvae and juveniles were transported northward by current (e.g., the Taiwan Warm Current and Kuroshio Current; Fig. 1). Previous studies reported that larval and juvenile $S$. dumerili were collected around Taiwan (Liu 2001; Chen et al. 2012), and thus $S$. dumerili may also have spawned around Taiwan in 2017.

In the present study, we could not determine the age of the YOY individuals with LTs greater than $10 \mathrm{~cm}$ collected on the western Japanese coast. Assuming that $S$. dumerili in the ECS show the same growth rate as those on the western Atlantic coast (Wells and Rooker 2004), S. dumerili will grow to $25 \mathrm{~cm}$ in SL within about 160 days after hatching. Accordingly, it is estimated that the YOY fish collected from July to September on the western Japanese coast were born in February to April. Thus, the spawning period of S. dumerili in the southern ECS and western Japanese coast may be overlapped, indicating transportation of larval and juvenile S. dumerili from the southern ECS to western Japanese coast. Synthesizing these results, we conclude that 
S. dumerili in the ECS is expected to spawn from late winter to early summer and to be transported to the Japanese coast from the southern ECS.

\section{Genetic variability}

By restricting analyses to YOY S. dumerili, it is likely that our samples reflected the genetic composition of the spawning population better than using older fish with greater migratory capacity (Graves et al. 1996; Carlsson et al. 2004). The high levels of variation in haplotypes of the mtDNA CR in $S$. dumerili supports our hypothesis that $S$. dumerili in the ECS is one population. This is because the minimum spanning network cladogram tree represented mixed distribution and there was no significant difference among the 4 groups with different geographical locations and years-i.e., the southern ECS and the western Japanese coast along the ECS in 2016 and 2017. In the present study, however, high haplotype diversities were observed and individuals from different locations shared several haplotypes with higher frequency, while the otolith analyses suggested that the spawning ground of $S$. dumerili in the ECS may be dispersedly formed. From these results, there are two interpretations regarding the variations of the mtDNA $\mathrm{CR}$ of $S$. dumerili in the ECS.

First, S. dumerili in the ECS is one population and variations of the mtDNA CR may result from significant levels of gene flow and/or transportation of individuals. In marine organisms, a pelagic larval stage increases the opportunities for long-distance dispersal and is often associated with little genetic differentiation over large geographical distances (Riginos and Victor 2001). For instance, marine fish species which have no or short pelagic larval phases show distinct regional genetic differentiation (Riginos and Victor 2001; Bernardi and Vagelli 2004). Based on our estimation, the larval phase of $S$. dumerili may be at least 30 days in the wild (Fig. 3 ), because $S$. dumerili reaches the juvenile stage at $1.1 \mathrm{~cm}$ in SL under rearing conditions (Tachihara et al. 1993). In addition, juveniles of $S$. dumerili of 1.7$29.7 \mathrm{~cm}$ in SL associate with floating objects such as drifting seaweeds (Badalamenti et al. 1995; Yamasaki et al. 2014; Hasegawa et al. 2017a). Since drifting seaweeds are passively transported by surface current (Komatsu et al. 2014), S. dumerili may also be passively dispersed even in the juvenile stage. Such a long passive dispersal period would enable $S$. dumerili to disperse over a geographically wide range, resulting in gene flow among geographically distant areas. Larval transportation by ocean currents is a key factor in the gene flow between geographically distant areas. For example, it has been confirmed that the Notothenioidei fish in the southern Scotia Arc, Antarctica showed low-population differentiation and high gene flow from microsatellites and mtDNA analyses (Damerau et al. 2012). As for the Japanese eel Anguilla japonica, no significant genetic differentiations were observed between specimens collected in East Asia by microsatellite DNA analysis (Han et al. 2010). In the ECS, the Kuroshio Current is assumed to be strongly related to the dispersal and genetic variability of $S$. dumerili (Fig. 1), since the Kuroshio Current affects the transportation of fish eggs, larvae and juveniles to the Japanese coast (e.g.,Sassa et al. 2008; Sassa and Tsukamoto 2010). Larvae and juveniles of $S$. dumerili hatched in the southern ECS may also be transported to the Japanese coast by the Kuroshio Current (Fig. 1), as presumed from the results of otolith analysis in the present study. Additionally, rearing experiments have revealed that the triggering factors for spawning of $S$. quinqueradiata (Mushiake et al. 1998) and S. dumerili (Hamada and Soyano 2009) are an increase in water temperature and the occurrence of a long photoperiod. Since the spawning ground of S. quinqueradiata may shift northward during the spawning season in the ECS (Yamamoto et al. 2007), similar shifts of spawning ground are expected in the congeneric species $S$. dumerili. Thus, adults of $S$. dumerili in the ECS may spawn in order with the northward shifting of optimum water temperature in the southern ECS. And larvae and juveniles would be mixed during transportation by the Kuroshio Current and the Tsushima Warm Current. This transportation system and long passive dispersal period of larvae may enhance the gene flow of $S$. dumerili, resulting in high haplotype diversity and no geographical genetic variability in the ECS.

Second, variations of the mtDNA CR of $S$. dumerili may result from multiple subpopulations in several regions in the ECS, because $S$. dumerili frequently concentrate around reefs, rock outcrops and wrecks (Manooch and Potts 1997). Therefore, S. dumerili is not assumed to migrate a greater distance compared to congeneric $S$. quinqueradiata, which shows extensive spawning migration (Yamamoto et al. 2007). If this is the case, high haplotype diversities occurred due to the difference of spawning timing and dispersal during the transportation. However, the ocean current system in the 
ECS may prevent the formation of subpopulations in the different locations in the ECS, while there is little information on the migration pattern of adult $S$. dumerili in the ECS. Further, previous studies suggested the existence of two subpopulations of $S$. dumerili in the SCS and Japanese coast (Nugroho et al. 2000; Araki et al. 2018). Therefore, it is likely that variations of the mtDNA CR result from significant levels of gene flow and/or transportation of individuals.

Perspectives and management of $S$. dumerili in the ECS

In 2014, the most produced aquaculture Seriola sp. in Japan was S. quinqueradiata at 107,059 tons, followed by $S$. dumerili at 38,770 tons (Sicuro and Luzzana 2016), and the production of $S$. dumerili continues to increase. The aquaculture seedlings of $S$. dumerili are mainly wild-caught juveniles from Japan and from the SCS (Nakada 2008), and S. dumerili in these two waters are recognized as genetically different populations (Nugroho et al. 2000; Araki et al. 2018). Our results indicate that the $S$. dumerili in Japanese waters are originated from the ECS, and that they may be spawned around Taiwanese waters, southern ECS. The catch of juvenile $S$. quinqueradiata as aquaculture seedlings is strictly managed by the Japanese government both in terms of the period and amount of the catch, and this fishery management successfully led to a high production of aquaculture and stable catch of wild yellowtail (Nakada 2008). However, there are no strict fishery regulations for $S$. dumerili juveniles either in Japan or Taiwan. Considering the increasing demand for S. dumerili seedlings in Japan, it is recommended that stock assessment and fishing regulations be developed as for yellowtail. Since the main spawning ground of S. dumerili in the ECS is assumed to be around Taiwanese waters, it will be important to promote international cooperation between Japan and Taiwan, who share the resource of $S$. dumerili, for the fishery management of this species, and for sustainable fisheries and aquaculture in general.

In conclusion, our results imply that $S$. dumerili in the ECS is composed of one population, probably due to physical dispersion and ecological features in the early life history of $S$. dumerili: spawning in an unconfined area around the shelf break region in the southern ECS from late winter to early summer, followed by transport of the larvae and juveniles to the Japanese coast by the Kuroshio Current. Since our study only examined differences in mtDNA with small sample size, it is necessary to investigate the genetic variation of S. dumerili using more DNA markers with higher variability (such as microsatellite DNAs) than the mtDNA CR over wider geographic scales and with larger sample sizes. Further, there is little information on the spawning ecology and migration pattern of S. dumerili in the ECS. Biologging of spawning adults together with examinations of gonadal development should be conducted in order to reveal the spawning ecology and migration pattern of $S$. dumerili in the ECS. This information may facilitate understanding of the genetic population structure of $S$. dumerili in the ECS.

Acknowledgements The authors wish to thank the crews of the R/V "Fishery Researcher 1" of the Fishery Research Institute, Council of Agriculture, Taiwan, and the R/V "Yoko-Maru" of the Seikai National Fisheries Research Institute, Fisheries Research and Education Agency, Japan. We also thank the crew of the T/V "Kakuyo-Maru" of Nagasaki University for their help during the research cruises. This study was financially supported by a Sasakawa Scientific Research Grant from the Japan Science Society (29-710) to T.H. and by Grants-in-Aid for Scientific Research from the Japan Society for the Promotion of Science to Y.S. and T.S. (16H05794, 19H00952) and to R.K. and K.K. (16H05795, 19H00952). All applicable international, national, and/or institutional guidelines for the care and use of animals were followed. All procedures performed in studies involving animals were in accordance with the ethical standards of the institution or practice at which the studies were conducted. This article does not contain any studies with human participants performed by any of the authors.

Open Access This article is licensed under a Creative Commons Attribution 4.0 International License, which permits use, sharing, adaptation, distribution and reproduction in any medium or format, as long as you give appropriate credit to the original author(s) and the source, provide a link to the Creative Commons licence, and indicate if changes were made. The images or other third party material in this article are included in the article's Creative Commons licence, unless indicated otherwise in a credit line to the material. If material is not included in the article's Creative Commons licence and your intended use is not permitted by statutory regulation or exceeds the permitted use, you will need to obtain permission directly from the copyright holder. To view a copy of this licence, visit http://creativecommons.org/licenses/by/4.0/.

\section{References}

Araki K, Aokic J, Kawase J et al (2018) Whole genome sequencing of greater amberjack (Seriola dumerili) for snp identification on aligned scaffolds and genome structural variation analysis using parallel resequencing. Int J Genomics 2018:112. https://doi.org/10.1155/2018/7984292 
Badalamenti F, D’Anna G, Lopiano L et al (1995) Feeding habits of young-of-the-year greater amberjack Seriola dumerili (Risso, 1810) along the N/W Sicilian Coast. Sci Mar 59: 317-323

Bernardi G, Vagelli A (2004) Population structure in Banggai cardinalfish, Pterapogon kauderni, a coral reef species lacking a pelagic larval phase. Mar Biol 145:803-810. https://doi. org/10.1007/s00227-004-1355-1

Carlsson J, McDowell JR, Díaz-Jaimes P et al (2004) Microsatellite and mitochondrial DNA analyses of Atlantic bluefin tuna (Thunnus thynnus thynnus) population structure in the Mediterranean Sea. Mol Ecol 13:3345-3356. https://doi.org/10.1111/j.1365-294X.2004.02336.x

Chen WY, Wang YC, Lee MA (2012) Early-summer ichthyoplankton biodiversity associated with oceanic factors on the continental shelf of the southern East China Sea. J Mar Sci Technol 20:698-706. https://doi.org/10.6119/JMST-0120727-1

Cummings NJ, Mcclellan DB (1996) Movement patterns and stock interchange of greater amberjack, Seriola dumerili in the southeastern U.S. U.S. Dept. of Comm., NOAA, NMFS, SEFSC, Miami Laboratory Cont. No. MIA-95/96 - 14. pp. 60

Damerau M, Matschiner M, Salzburger W, Hanel R (2012) Comparative population genetics of seven notothenioid fish species reveals high levels of gene flow along ocean currents in the southern Scotia Arc, Antarctica. Polar Biol 35:10731086. https://doi.org/10.1007/s00300-012-1155-x

Excoffier L, Lischer HEL (2010) Arlequin suite ver 3.5: a new series of programs to perform population genetics analyses under Linux and Windows. Mol Ecol Resour 10:564-567. https://doi.org/10.1111/j.1755-0998.2010.02847.x

Excoffier L, Smouse PE, Quattro JM (1992) Analysis of molecular variance inferred from metric distances among DNA haplotypes: application to human mitochondrial DNA restriction data. Genetics 131:479-491. https://doi.org/10.3354 /meps198283

Fahay MP (1975) An annotated list of larval and juvenile fishes captured with surface-towed meter net in the South Atlantic bight during four RV Dolphin Cruises between May 1967 and February 1968. NOAA Tech Rep NMFS SSRF 685:139

Fujita S, Mori I (1982) Basic investigation for the conservation of yellowtail Seriola quinqueradiata juveniles in the wild. In: Japan Sea-Farming Association (ed) Basic investigation for the conservation of yellowtail Seriola quinqueradiata juveniles in the wild, Japan Sea-Farming Association, Tokyo, pp 53-80 (in Japanese)

Fukataki H (1960) Consideration of the recruiting process of the jack-mackerel population in the Tsushima Current region. I. Consideration from occurrence and distribution of larvae. Ann Rep Jpn Sea Reg Fish Res Lab 6:69-85 (in Japanese with English abstract)

Gold JR, Richardson LR (1998) Population structure in greater amberjack, Seriola dumerili, from the Gulf of Mexico and the western Atlantic Ocean. Fish Bull 96:767-778

Graves J, Gold J, Ely B et al (1996) Population genetic structure of bluefin tuna in the North Atlantic Ocean. Identification of variable genetic markers. Collect Vol Sci Pap 45:155-157

Hamada K, Soyano K (2009) Studies on reproductive cycle and advanced spawning of Greater amberjack Seriola dumerili
In: Midori Shobo Co. Ltd. (ed) Aquaculture Magazine, Midori Shobo Co. Ltd., Tokyo, pp 25-27 (in Japanese)

Han YS, Hung CL, Liao YF, Tzeng WN (2010) Population genetic structure of the Japanese eel Anguilla japonica: panmixia at spatial and temporal scales. Mar Ecol Prog Ser 401: 221-232. https://doi.org/10.3354/meps08422

Harris PJ, Wyanski DM, White DB et al (2007) Age, growth, and reproduction of greater amberjack off the Southeastern U.S. Atlantic Coast. Trans Am Fish Soc 136:1534-1545. https://doi.org/10.1577/T06-113.1

Hasegawa T, Takatsuki N, Kawabata Y et al (2017a) Continuous behavioral observation reveals the function of drifting seaweeds for Seriola spp. juveniles. Mar Ecol Prog Ser 573: 101-115. https://doi.org/10.3354/meps12154

Hasegawa T, Yeh H-M, Chen J-R et al (2017b) Collection and aging of greater amberjack Seriola dumerili larvae and juveniles around the Penghu Islands, Taiwan. Ichthyol Res 64: 145-150. https://doi.org/10.1007/s10228-016-0543-6

Komatsu T, Mizuno S, Natheer A et al (2014) Unusual distribution of floating seaweeds in the East China Sea in the early spring of 2012. J Appl Phycol 26:1169-1179. https://doi. org/10.1007/s10811-013-0152-y

Kumar S, Stecher G, Li M et al (2018) MEGA X: Molecular evolutionary genetics analysis across computing platforms. Mol Biol Evol 35:1547-1549. https://doi.org/10.1093 /molbev/msy096

Liu CH (2001) Early osteological development of the yellow tail Seriola dumerili (Pisces: Carangidae). Zool Stud 40:289-298

Manooch CS, Potts JC (1997) Age, growth and mortality of greater amberjack from the southeastern United States. Fish Res 30:229-240

Mushiake K, Kawano K, Kobayashi T, Yamasaki T (1998) Advanced spawning in yellowtail, Seriola quinqueradiata, by manipulations of the photoperiod and water temperature. Fish Sci 64:727-731. https://doi.org/10.2331/fishsci.64.727

Nakada M (2002) Yellowtail culture development and solutions for the future. Rev Fish Sci 10:559-575. https://doi. org/10.1080/20026491051794

Nakada M (2008) Capture-based aquaculture of yellowtail. In: Lovatelli A, Holthus PF (eds) Capture-based aquaculture: global overview. FAO Fisheries Technical Paper, Rome, pp 199-215

Nugroho E, Taniguchi N, Kato K, Miyashita S (2000) Genetic difference among seed populations of greater amberjack used in aquaculture farm of Japan. Aquac Sci 48:665674. https://doi.org/10.11233/aquaculturesci1953.48.665

Okiyama M (1988) An atlas of the early stage fishes in Japan. Tokai Univ Press, Tokyo (in Japanese)

Okiyama M (2014) An atlas of early stage fishes in Japan second edition. Tokai Univ Press, Kanagawa (in Japanese)

Oozeki Y, Kimura R, Kubota H, Ishida M (2001) Modified neuston net for collecting larvae and juveniles of Pacific saury, Cololabis saira. Bull Jpn Fish Ocean 65:1-5 (in Japanese with English abstract)

Posada D, Crandall KA (2001) Intraspecific gene genealogies: Trees grafting into networks. Trends Ecol Evol 16:3745. https://doi.org/10.1016/S0169-5347(00)02026-7

Raya V, Sabatés A (2015) Diversity and distribution of early life stages of carangid fishes in the northwestern Mediterranean: responses to environmental drivers. Fish Oceanogr 24:118134. https://doi.org/10.1111/fog. 12097 
Riginos C, Victor BC (2001) Larval spatial distributions and other early life-history characteristics predict genetic differentiation in eastern Pacific blennioid fishes. Proc R Soc B Biol Sci 268:1931-1936. https://doi.org/10.1098/rspb.2001.1748

Rozas J, Ferrer-Mata A, Sánchez-DelBarrio JC et al (2017) DnaSP 6: DNA sequence polymorphism analysis of large data sets. Mol Biol Evol 34:3299-3302. https://doi.org/10.1093 $/ \mathrm{molbev} / \mathrm{msx} 248$

Sassa C, Tsukamoto Y (2010) Distribution and growth of Scomber japonicus and $S$. australasicus larvae in the southern East China Sea in response to oceanographic conditions. Mar Ecol Prog Ser 419:185-199. https://doi.org/10.3354/meps08832

Sassa C, Tsukamoto Y, Nishiuchi K, Konishi Y (2008) Spawning ground and larval transport processes of jack mackerel Trachurus japonicus in the shelf-break region of the southern East China Sea. Cont Shelf Res 28:2574-2583. https://doi. org/10.1016/j.csr.2008.08.002

Sassa C, Takahashi M, Konishi Y, Tsukamoto Y (2016) Interannual variations in distribution and abundance of Japanese jack mackerel Trachurus japonicus larvae in the East China Sea. Mar Sci 73:1170-1185. https://doi. org/10.1093/icesjms/fsv269

Sedberry GR, Pashuk O, Wyanski DM et al (2006) Spawning locations for Atlantic reef fishes off the Southeastern U. S. Proceedings of the 57th Annual Gulf and Caribbean Fisheries Institute 57:463-514

Sicuro B, Luzzana U (2016) The state of Seriola spp. Other than yellowtail (S. quinqueradiata) farming in the world. Rev Fish Sci Aquac 24:314-325. doi:https://doi.org/10.1080 $/ 23308249.2016 .1187583$

Tachihara K, Ebisu R, Tsukashima Y (1993) Spawning, eggs, larvae and juveniles of the purplish amberjack Seriola dumerili. Nippon Suisan Gakkaishi 59:1479-1488 (in Japanese with English abstract). https://doi.org/10.2331 /suisan.59.1479

Taki Y, Kohno H, Sakamaot K, Hosoya K (2005) Illustrated fishes in colour revised edition. Hokuryukan Co. Ltd., Tokyo (in Japanese)

Thompson JD, Higgins DG, Gibson TJ (1994) CLUSTAL W: improving the sensitivity of progressive multiple sequence alignment through sequence weighting, position-specific gap penalties and weight matrix choice. Nucleic Acids Res 22: 4673-4680. https://doi.org/10.1093/nar/22.22.4673

Uchida K, Imai S, Mito S, Fujita S, Ueno M, Shojima Y, Senta T, Tahuku M, Dotsu Y (1958) Studies on the eggs, larvae and juvenile of Japanese fishes Series 1. Second Lab Fish Biol Fish Dep Fac Agri Kyushu Univ, Fukuoka (in Japanese)

Untergasser A, Cutcutache I, Koressaar T, Ye J, Faircloth BC, Remm M, Rozen SG (2012) Primer3 - new capabilities and interfaces. Nucleic Acids Res 40:e115. https://doi. org/10.1093/nar/gks596

Wells RJD, Rooker JR (2004) Distribution, age, and growth of young-of-the-year greater amberjack (Seriola dumerili) associated with pelagic Sargassum. Fish Bull 102:545-554

Yamamoto T, Ino S, Kuno M et al (2007) On the spawning and migration of yellowtail Seriola quinqueradiata and research required to allow catch forecasting. Bull Fish Res Agen 21:129

Yamasaki M, Aono M, Ogawa N et al (2014) Drifting algae and fish: Implications of tropical Sargassum invasion due to ocean warming in western Japan. Estuar Coast Shelf Sci 147:32-41. https://doi.org/10.1016/j.ecss.2014.05.018 